\title{
6 Federal institutional design and the COVID-19 crisis management in Bosnia and Herzegovina
}

\author{
Nina Sajic
}

\subsection{Introduction}

Bosnia and Herzegovina is a federal country consisting of two entities: the Federation of Bosnia and Herzegovina and the Republika Srpska. Sandwiched between the two is a special region: the Brčko District, a multi-ethnic district with its own Government and Parliament. While often characterized by some as a frozen conflict, or a fragile and dysfunctional country that is unstable and in danger of collapse, Bosnia and Herzegovina has evolved since the war ended in 1995 (see Kartsonaki 2016).

However, a lack of mutual trust exists among key political figures at the central level and at the level of constituent units. There are divergent views on the future of the country, and political parties are divided along ethnic/linguistic lines. There is domestic rivalry between those advocating more autonomy and those with centralist aspirations. This rivalry seems to be the primary generator of internal conflict and tensions in Bosnia and Herzegovina.

The Republic Srpska (RS) demands more autonomy because the current constitutional arrangements are not efficient. Bosniak political elites use the same argument to ask for tighter centralization. The complexity of institutional structures of Bosnia and Herzegovina was not, according to Stroschein (2003), produced by accident. Yet, the asymmetric and complex governing institutions were introduced for one simple goal: to ensure that groups, which disagree on the nature of governance, could coexist. ${ }^{1}$

How did the federal architecture of Bosnia and Herzegovina with its asymmetric nature cope with the COVID-19 crisis? The answers found in this chapter show how various orders of government managed the crisis, the contents of their strategy, the nature of their relations, and the roles of constituent units and the central level during the pandemic. There is a brief overview of the pandemic, its impact on the economy, and the people.

The federal institutional design, with its competencies and powers related to the COVID-19 pandemic, guided the measures and actions each order of government took and how those measures were coordinated. One might expect that the fragility of the federal architectural design of Bosnia and Herzegovina would come to the forefront in a time of crisis such as COVID-19. Instead, the chapter concludes that the institutions of Bosnia and Herzegovina responded relatively well regardless of their flaws. All the internal issues did not disappear during the crises; on the contrary, political conflict arose several times between the government's different orders. Some have seen the pandemic as a window of opportunity to strengthen the central level, whereas others saw the pandemic as the chance to strengthen the autonomy of their constituent units. Although at

DOI: $10.4324 / 9781003251217-6$ 
50 Nina Sajic

Table 6.1 Key Statistics on COVID-19 in Bosnia and Herzegovina as of 10 January 2021.

\begin{tabular}{lllll}
\hline $\begin{array}{l}\text { Cumulative } \\
\text { Cases }\end{array}$ & $\begin{array}{l}\text { Cumulative Cases per } \\
\text { 100,000 Population }\end{array}$ & $\begin{array}{l}\text { Cumulative } \\
\text { Deaths }\end{array}$ & $\begin{array}{l}\text { Cumulative Deaths per } \\
100,000 \text { Population }\end{array}$ & $\begin{array}{l}\text { Case Fatality } \\
\text { Percentage }\end{array}$ \\
\hline 115,379 & $3,516.8$ & 4,305 & 131.2 & 3.7
\end{tabular}

Source: World Health Organization Weekly epidemiological update - 12 January 2021. Geneva: WHO, 2021. Available from https:/www.who.int/publications/m/item/weekly-epidemiological-update

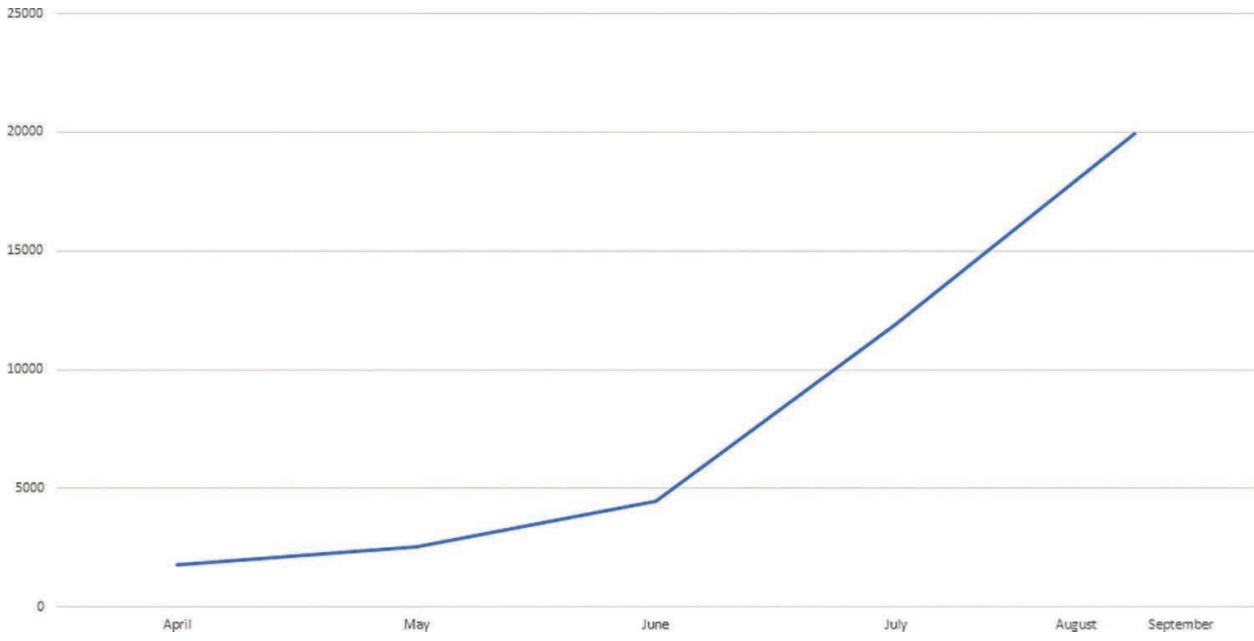

Figure 6.1 Total Number of COVID-19 Cases in Bosnia and Herzegovina from April to September 2020.

Source: The Ministry of Civil Affairs of B\&H. Available from: http://mcp.gov.ba/publication/read/ epidemioloska-slika-covid-19? pageId=3 [Accessed 4 September 2020].

first, every order of government in Bosnia and Herzegovina sought to act on its own, in the end, the country did respond to the challenge of COVID-19 (Table 6.1).

\subsection{COVID-19 in Bosnia and Herzegovina}

The first COVID-19 infected patient in the country was registered in Banja Luka, an administrative center of the Republika Srpska, on 5 March 2020. Four days later, the first patient was registered in the Federation of Bosnia and Herzegovina. By the end of March, there were 420 people infected, and the death toll was 13. Figure 6.1 shows the total number of cases in Bosnia and Herzegovina from April to September 2020. As the graph demonstrates, the outbreak was successfully controlled during the spring of 2020 due to the authorities' restrictive measures and the approach taken at all levels. To ease pressure on the relatively under-resourced health care system and avoid the scenarios played out in Italy and Spain, the entities in Bosnia and Herzegovina introduced preventive and restrictive measures at the early stages of the epidemic. The restrictive public health measures were gradually lifted, beginning in May.

Although the health sector is highly decentralized in Bosnia and Herzegovina, the epidemiological situation is managed, monitored, and reported by several orders of 


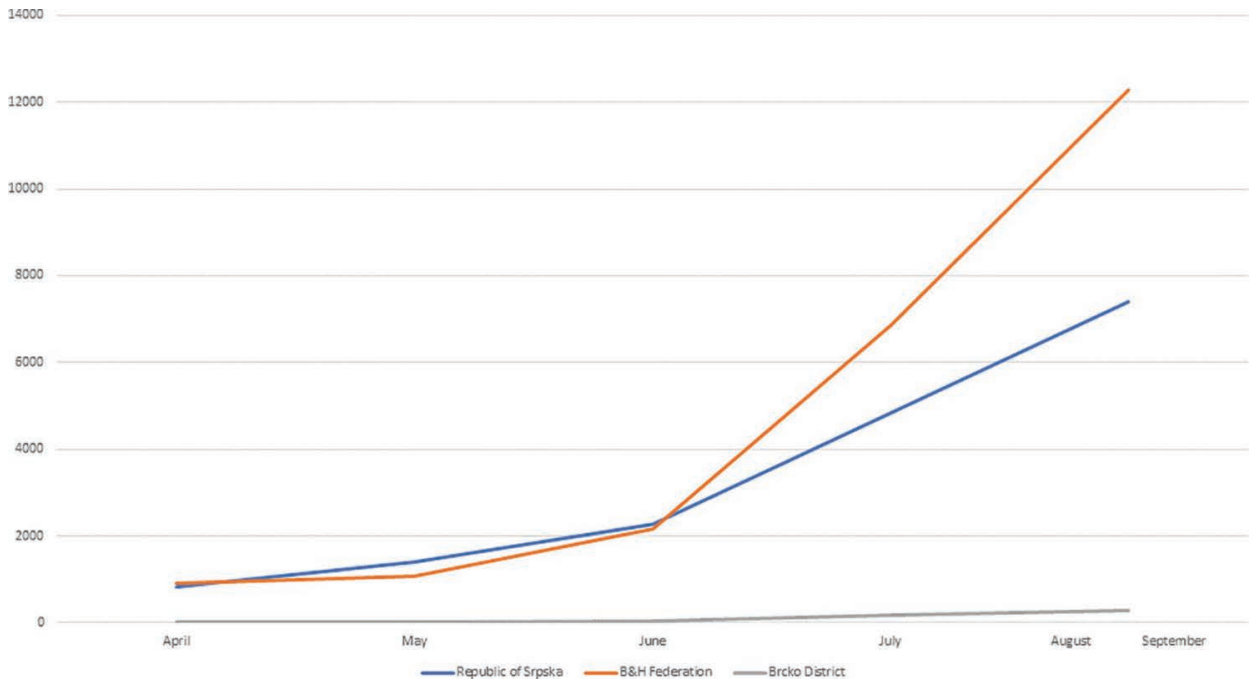

Figure 6.2 Distribution of COVID-19 Cases in FB\&H, RS, and the Brčko District in 2020.

Source: The Ministry of Civil Affairs of Bosnia and Herzegovina. Available from: http://mcp.gov.ba/ publication/read/epidemioloska-slika-covid-19?pageId=3 [Accessed 2 September 2020].

government: the entities, the cantons, and the Brčko District. Figure 6.2 shows the distribution of COVID-19 cases in the entities and the Brčko District.

As both graphs show, early July 2020 marked the resurgence of COVID-19 cases within the entire territory of Bosnia and Herzegovina. There were 20,804 people infected and a death toll of 636 at the beginning of September 2020. The new surges in cases were a result of non-compliance with protective measures. Not wearing masks and not practicing physical distancing drove the surge, according to the officials and medical practitioners.

While the aggressive strategy was aimed to reduce human and health costs, it has nevertheless contributed to a negative impact on the economy. The country was headed into a recession, together with other Western Balkan countries. Despite its troubled past, Bosnia and Herzegovina is an upper middle-income country, according to the World Bank's classification (World Bank 2020), although it now has a significant unemployment rate of 15.7 percent (Agency for Statistics of Bosnia and Herzegovina). Bosnia and Herzegovina had a slow recovery from the economic crisis of 2008. In 2014, the country was affected by unprecedented floods with damages and losses that cost around 15 percent of its annual GDP (World Bank Group 2020).

As in many other European countries, not all the sectors and economic activities were affected in the same way. Some sectors, such as medical suppliers and pharmacies, which were considered essential, remained fully active and even had increased economic activities. Those considered non-essential, such as tourism, leisure, hotels, restaurants, beauty salons, and educational facilities, were completely shut down and have suffered the most. Between these two categories were sectors not closed by the any government, but their activities were reduced due to other confinement measures. 


\section{Nina Sajic}

These sectors included legal and accounting activities, various manufacturing activities, plus imports, and exports.

While there are still no reliable data accounting for the impact of COVID-19 on the overall economic costs of the virus, officials estimate that the overall GDP in Bosnia and Herzegovina will fall between 3.5 percent and 5 percent. The unemployment rate since the beginning of the pandemic until the end of June went up by 4.6 percent (Labour and Employment Agency of Bosnia and Herzegovina 2020). The income from exports was down by 15.1 percent and import income declined by 18 percent in the first half of the year (Banjaluka.net 2020). Industrial production in April and May was about 16 percent below the output levels of 2019 (European Commission 2020). The economic tolls of COVID-19 can also be seen through value-added tax (VAT) collection. From January to August 2020, VAT collection was 10.6 percent lower than in the same period of 2019, resulting in a lower distribution of VAT revenues (Indirect Taxation Authority of Bosnia and Herzegovina $2020)^{2}$ than in 2019. For the Federation of Bosnia and Herzegovina, it was 12.1 percent lower. For Republika Srpska, it was 7.4 percent lower, and for the Brčko District, it was 12.4 percent lower (Indirect Taxation Authority of Bosnia and Herzegovina, 5 September 2020).

\subsection{COVID-19 and federalism in Bosnia and Herzegovina}

Although the Constitution of Bosnia and Herzegovina does not define the country as a federal state per se, its institutional architectural features and characteristics are common to all federal countries (General Framework Agreement for Peace in Bosnia and Herzegovina 1995). ${ }^{3}$

The federal institutional design was introduced, or rather, imposed, by the international community in Dayton, Ohio, USA, in 1995 in order to resolve a four-year civil conflict in Bosnia and Herzegovina. The constitution recognizes Bosniaks, Croats, and Serbs (along with Others) as constituent peoples. The two entities of the country the Federation of Bosnia and Herzegovina (mostly inhabited by Bosniaks and Croats) and the Republic of Srpska (with a Serb majority) - each have their own presidents, governments, parliaments, and constitutions. The Republic of Srpska is centralized, while the Federation of Bosnia and Herzegovina is further divided into ten cantons, each having its own government, parliament, and judicial powers.

The decentralization of the Federation of Bosnia and Herzegovina is based on the so-called Washington Agreement (The General Framework on the Federation 1994) between Bosniaks and Croats signed in 1994. As a result of that agreement, there are five cantons with a Bosniak majority, three with a Croat majority and two are "ethnically mixed." There is also the Brčko District, a self-governing administrative unit under the sovereignty of Bosnia and Herzegovina, whose territory is shared by both entities. One of the particularities of this asymmetrical federal institutional design of Bosnia and Herzegovina is a rotating Presidency. There are three members of the Presidency, each representing one of the constituent peoples - Bosniaks, Croats, and Serbs. These three presidents are primus inter pares (first among equals) and are directly elected for a four-year mandate.

The powers of the state institutions are clearly specified, and residual powers remain with the governments of the entities. All the powers not expressly granted to the central government are vested in two entities: the Republic of Srpska and the Federation of Bosnia and Herzegovina. In the Federation of Bosnia and Herzegovina, these 
powers are distributed between the entity and the cantons in such a way that all the powers that are not expressly given to this entity by its constitution are vested in the cantons. The federal institutions have limited competencies in the health sector, including the definition of international strategies, the coordination and harmonization of the plans of the two entities, and the establishment and supervision of a unified market for medical devices. The entities and the Brčko District, on the other hand, have extensive powers in the health sector. The Republic of Srpska has a centralized healthcare system, while in the Federation of Bosnia and Herzegovina, healthcare is a shared competence between the entity government and the ten cantons.

Most of the other powers related to COVID-19 crisis management do not belong to the central level, but fall under the jurisdiction of the entities:

- Internal restrictions on movement of people and goods

- Education

- Financial stimulus packages

- Work permits and working hours

- Public transportation

- Social welfare

- Curfews

- Economic recovery and development measures

In the Federation of Bosnia and Herzegovina, these powers are also shared competencies with cantons. The powers that belong to Bosnia's central government include international loan arrangements, border control, repatriation of citizens, use of the armed forces, coordination of entities' civil protection units, and harmonization of their plans in the event of natural or other disasters in Bosnia and Herzegovina.

The COVID-19 crisis has been managed mostly by the entities, cantons, and the Brčko District, with a somewhat limited role of the central government institutions. In the Republic of Srpska, the pandemic risk manager has been the Emergency Situation HQ. This is an ad hoc committee, chaired by the Republic of Srpska prime minister, which comes together to manage emergencies during times of crisis. In the Federation of Bosnia and Herzegovina, the Federal Department of Civilian Protection has managed the response to the COVID-19 outbreak. Each canton has its own crisis units or disease control centers within their respective ministries of health. In the Brčko District, the Protection and Rescue HQ chaired by the district's mayor has managed the crisis. Crisis Units within local communities are responsible for taking on measures such as business hours and closing or opening of economic activities. Orders and decisions taken by these Crisis Units may override decisions taken by higher orders of government it they are more restrictive and until a state of emergency has been declared.

From the onset of the pandemic, there was a lack of coordination and cooperation between the entities. However, both have taken a cautious approach and early control strategy to fight the pandemic. The Republic of Srpska was first to introduce preventive and restrictive measures. It imposed a ban on all public gatherings, closed the universities, schools and kindergartens, and limited business hours in certain cities. The Federation of Bosnia and Herzegovina followed the Republic of Srpska's example after a few days of delay. This delay, in turn, caused strong reactions from that entity's officials, who felt that this would undermine their own measures' effectiveness. On 16 March 2020, the Republic of Srpska declared an emergency and the Federation 


\section{Nina Sajic}

of Bosnia and Herzegovina declared a status of disaster. The first institution of Bosnia's central government to react to the pandemic was the tripartite Presidency of the country, which adopted 18 measures regarding the COVID-19 crisis. These included, among other things, orders to the Bosnia and Herzegovina Armed Forces to put all of their resources at the disposal of the government to tackle the crisis, a request to the central Council of Ministers to declare a situation of natural or other disaster in the whole territory of the country, and support for introducing a quarantine at border crossings (Presidency 2020). The Bosnia and Herzegovina Council of Ministers declared a state of natural or other disaster in the country. The council first restricted the entry of people from countries affected by the pandemic, before deciding to temporarily shut down borders for all foreigners with few exceptions, and organized the repatriation of citizens of Bosnia and Herzegovina who were abroad. To help domestic companies, the central government's Council of Ministers adopted a decision to give preference to domestic companies bidding on public tenders. This decision will be effective for one year (Council of Ministers 2020).

In Bosnia's central government, the preventive measures adopted were not always coordinated and respected by other levels of government. A case in point is the Bosnia and Herzegovina Presidency's initiative to introduce quarantine stations near border crossings for people entering the country. At first, this initiative was only implemented by the Republic of Srpska. The Federation of Bosnia and Herzegovina took action on this measure following two weeks of delay, and only after the federal Presidency decided to shut border crossings that did not have quarantine stations.

COVID-19 mitigation measures were taken by both entities - measures such as the introduction of curfews, the closing down of shops, provision of financial and other assistance to the economy, and the organization of online courses for pupils and students. Exemptions were made for pharmacies and grocery stores. The measures were quite similar between the two entities ${ }^{4}$ and were taken simultaneously. This was not so much a result of the coordination between the entities, but more due to the competitive nature of their relations. There have also been cases of conflict-laden and tense inter-governmental relations between the Federation of Bosnia and Herzegovina and its cantons, especially those with a Croat majority. At the beginning of the pandemic, Canton 10 (which has a Croat majority) banned the entry and transit of Bosnia and Herzegovina citizens through its territory. While for this cantonal government, the measure was introduced to protect its population, for the Prime Minister of the Federation of Bosnia and Herzegovina (a Bosniak), this measure was an "attack on constitutional order," (Fena News Agency 2020). The cantonal order was revoked almost immediately, however, because it was seen as an attempt of the Croat majority canton to strengthen its autonomy.

Declaring a state of emergency at the beginning of April 2020 allowed the Republic of Srbska to enact decrees and regulations related to the pandemic with faster legal force, including to the provision of business subventions and assistance. The Federation of Bosnia and Herzegovina passed the so-called "Corona Law" a month later to help the economic recovery of affected businesses. The Brčko District also adopted the "Corona Law" at the beginning of May 2020.

There has been no coordination between the entities on their plans to ease the lockdown measures. The Federation of Bosnia and Herzegovina revoked its curfew and quarantine stations a few weeks before the Republic of Srpska did, which once again sparked intense opposition in the Republic. 
Constituent units have mostly managed the economy during the crisis because Bosnia's central government has practically no jurisdiction over the economy. There are still no exact figures on the financial resources that will be spent by all governments in Bosnia and Herzegovina. However, all governments have implemented measures to fight the pandemic - the entities, the cantons, the Brčko District, and local communities. According to the available data, the entities have spent around 25 million euros each to purchase medical equipment and supplies (International Monetary Fund 2020). For the Federation of Bosnia and Herzegovina, this spending was around 1 percent of its annual budget and for the Republic of Srpska around 1.5 percent. As a first wave response to fight COVID-19, the Republic of Srpska allocated around 5 percent of its annual budget (RTRS 2020), which included the purchase of the medical equipment and measures to mitigate the economic impact of the pandemic. In the Federation of Bosnia and Herzegovina, these figures are even less precise as both their government, and the governments of its cantons have financed various measures during the pandemic. Local communities also have taken their share of the financial burden. For example, Banja Luka, the second-largest city in the country, allocated around 3.5 percent of its annual budget as a response to the pandemic (BL Portal 2020).

The entities introduced similar fiscal measures, although once again without any coordination and consultation. For example, the Republic of Srpska covered personal income tax and social security contributions for about 40,000 workers in the sectors that were closed by government decision from March to May 2020. The Republic of Srpska also paid minimum salaries for all employees in these sectors in April, totalling about 1.6 percent of its annual budget (Policy Tracker 2020). The Federation of Bosnia and Herzegovina subsidized contributions and taxes and paid minimum wages for employees of the companies impacted by COVID-19 but only if their headquarters was registered in that entity (Policy Tracker 2020). This measure led to discrimination by the Republic of Srpska against the companies that also operate in the Federation of Bosnia and Herzegovina since these companies were excluded from the subsidies. However, companies from the Federation of Bosnia and Herzegovina that operate in the Republic of Srpska had equal treatment there. Both entities set up special funds to mitigate the pandemic's economic impacts and facilitate access to funds for companies once again without any prior coordination or consultation.

The conflictual and even obstructive nature of intergovernmental relations in Bosnia and Herzegovina resurfaced over the acquisition of medical equipment and supplies and in relation to international aid. Bosnia's central government first tried to obstruct one of the constituent units. ${ }^{5}$ Then, internal disputes between Bosniak and Croats also led to blocking an emergency loan from the International Monetary Fund. The IMF emergency loan was aimed to help Bosnia and Herzegovina address the COVID-19 crisis. However, the Bosniak ministers at the Council of Ministers objected to it, primarily because of their disagreement over the distribution of money between the Federation of Bosnia and Herzegovina and its ten cantons.

\subsection{Conclusion}

In cooperative decision-making among different governments, trust is the "oil" which makes the process go smoothly. "Without it, gridlock and polarization are more likely to surface and to remain a feature of politics, notwithstanding the arrival of a 


\section{Nina Sajic}

(fragile) agreement" (Swendon 2013). The competitive nature of federalism in Bosnia and Herzegovina, coupled with the lack of trust and the presence of animosity among Bosniaks, Croats, and Serbs, creates a space for disputes over powers and responsibilities as well as conflicts of interest. As Marciacq (2015) rightly observes, the three constituent peoples of Bosnia and Herzegovina have divergent views on their country's future and how the state should evolve. Their mutual level of trust remains relatively low, especially at the grassroots levels (Marciacq 2015).

For any federal state's functioning, intergovernmental cooperation is required, but in multinational federations such as Bosnia and Herzegovina, achieving harmonious collaboration among the central authorities and the constituent units often represents a challenge. This is especially the case in matters that directly concern or fall under the jurisdiction of constituent units, as do many aspects of COVID-19 crisis management.

The COVID-19 crisis did not bring about any new transformation in the practice of federalism in Bosnia and Herzegovina; if anything, it has only deepened the existing divisions and polarizations. However, Bosnia and Herzegovina managed to do relatively well during the first wave of the pandemic despite all the flaws and complexity of its federal institutional design. This was partly due to the competitive intergovernmental relations and partly because the constituent units in Bosnia and Herzegovina, during the COVID-19 crisis, were left on their own as was the case with many European countries. At the onset of the crisis, there was a complete absence of solidarity and cooperation in Europe, even within the EU, where some of its member states introduced export bans on certain medical supplies. ${ }^{6}$ The constituent units took the "every man for himself" strategy as their immediate response to the crisis. For those advocating more autonomy, such as the Republic of Srpska and the cantons with a Croat majority, this was a window of opportunity to pursue that goal. The others have tried to strengthen the central government with the obstruction of various measures. The COVID-19 crisis was not the first crisis that tested the country's federal institutional design. During the unprecedented floods that affected Bosnia and Herzegovina in 2014, the constituent units managed the crisis with the central government being inefficient and obstructive. We are yet to see to what extent the COVID-19 pandemic may lead to any reassignment of new responsibilities or the creation of more effective mechanisms of intergovernmental cooperation.

\section{Notes}

1 The Federation of Bosnia and Herzegovina refers to one of the constituent units (entities) of Bosnia and Herzegovina. Contrary to what its name suggests, it does not refer to the whole country of Bosnia and Herzegovina, but just to one part. The Federation of Bosnia and Herzegovina is further divided into ten cantons.

2 The VAT system was introduced in Bosnia and Herzegovina in 2006. Distribution of VAT revenues between the central government, the entities, and the Brčko District is regulated by the Law on Payments into the Single Account and Distribution of Revenues as well as decisions on a partition coefficient that is being determined every year. For more, see Indirect Taxation Authority of Bosnia and Herzegovina http://www.new.uino.gov.ba/en/ General-information-on-VAT-system-in-Bosnia-and-Herzegovina.

3 “...two orders of government, distribution of legislative and executive authority defined by a constitution, allocation of revenues between two orders of government, representation of constituent units in central decision-making institutions, a supreme constitution that cannot be amended without a consent of significant proportion of its constituent 
units, an arbitrary or umpire to decide on potential disputes between different orders of government, arrangements (institutions or processes) for intergovernmental cooperation." Ronald L. Watts, Comparing Federal Systems (London, Montreal and Kingston: McGillQueen's University Press, 1999), 7.

4 In the Federation of Bosnia and Herzegovina, some of these measures were introduced by Cantons as they fall directly into their jurisdiction.

5 As an illustration, one could highlight the international aid provided to the Republic of Srpska by Hungary and the Russian Federation upon the request of the Serb member of the Bosnia and Herzegovina Presidency. The B\&H Minister of Foreign Affairs (Bosniak) officially complained to the ministers of Foreign Affairs of these countries, as well to the EU, for not also sending medical aid to the other entity as well, although the Federation of Bosnia and Herzegovina never formally requested any assistance from Russia or Hungary.

6 For example, France requisitioned both the stocks and production of protective masks in the country.

\section{Bibliography}

Agency for Statistics of Bosnia and Herzegovina [dataset]. Annual indicators 2019, Available from: https://bhas.gov.ba/Home/ [Accessed 15 August 2020].

Banjaluka.net, 21 July 2020. Analiza: Korona vise usporila uvoz nego izvoz [online]. Available from: https://banjaluka.net/analiza-korona-vise-usporila-uvoz-nego-izvoz-iz-bih/ [Accessed 16 March 2021].

BL Portal, 10 September 2020. Korona odnijala milione iz lokalnih budzeta u RS [online]. Available from: https://www.bl-portal.com/drustvo/korona-odnijela-milione-iz-lokalnihbudzeta-u-rs/ [Accessed 16 March 2021].

Council of Ministers of Bosnia and Herzegovina, 29 May 2020. Council of Ministers Holds Its Extraordinary Phone Session.

European Commission: Directorate-General for Economic and Financial Affairs, July 2020. EU Candidate Countries' \& Potential Candidates' Economic Quarterly (CCEQ), 2nd Quarter 2020, Technical Paper 042. Available from: https://ec.europa.eu/info/sites/info/ files/economy-finance/tp042_en.pdf [Accessed 16 March 2021].

Fena News Agency, 22 March 2020. Novalic: The Order Issued by Canton 10 an Attack on the Constitutional Order [online]. Available from: https://www.fena.news/bih/novalic-the-orderissued-by-canton-10-an-attack-on-the-constitutional-order/ [Accessed 16 March 2021].

General Framework Agreement for Peace in Bosnia and Herzegovina 1995 available from the U.S. Department of State https://2009-2017.state.gov/p/eur/rls/or/dayton/52577.htm

General Framework on the Federation 1994, available from the UN Peacemaker https:// peacemaker.un.org/sites/peacemaker.un.org/files/BA_940301_FrameworkAgreement OnTheFederation.pdf

Indirect Taxation Authority of Bosnia and Herzegovina, 2021. General Information on VAT System in Bosnia and Herzegovina. Available from: http://www.new.uino.gov.ba/en/Generalinformation-on-VAT-system-in-Bosnia-and-Herzegovina [Accessed 16 March 2021].

Indirect Taxation Authority of Bosnia and Herzegovina. Information Received by Email Correspondence, 5 September 2020.

International Monetary Fund, 2020. Policy Tracker: Bosnia and Herzegovina, Key Policy Responses as of August 13, 2020. Available from: https://www.imf.org/en/Topics/imf-andcovid19/Policy-Responses-to-COVID-19\#B [Accessed 20 August 2020].

Kartsonaki, A., 2016. Twenty Years after Dayton: Bosnia-Herzegovina (Still) Stable and Explosive. Civil Wars, 18 (4), 488-516.

Labour and Employment Agency of Bosnia and Herzegovina, 5 August 2020. Labour Market Overview, Situation as of 30 June 2020.

Marciacq, F., 2015. Sub-state Diplomacy in Malfunctioning States: The Case of the Republika Srpska, Bosnia and Herzegovina. Regional and Federal Studies, 25 (4), 340. 


\section{Nina Sajic}

Ministry of Civil Affairs of Bosnia and Herzegovina, 2020. Epidemiološka slika (Covid 19). Available from: http://mcp.gov.ba/publication/read/epidemioloska-slika-covid-19? pageId= 3 [Accessed 4 September 2020].

Policy Tracker: Bosnia and Herzegovina. "Key Policy Responses as of August 13, 2020.”

Presidency of Bosnia and Herzegovina, 16 March 2020. BiH Presidency Holds Its 56th Extraordinary Session. Available from: http://predsjednistvobih.ba/zaklj/sjed/default. aspx?id=87858\&langTag=en-US [Available 16 March 2020].

RTRS 3 June 2020. Available from: https://lat.rtrs.tv/vijesti/vijest.php?id=386742 [Accessed 16 March 2020].

RTRS, 3 June 2020. Vidovic: Sredstva of MMF-a bice ulozena u zdravstvo i privredu.

Stroschein, S., 2003.What Belgium Can Teach Bosnia: The Use of Autonomy in 'Divided House' States. Journal of Ethnopolitics and Minority Issues in Europe, 3, 22.

Swenden, W., 2013. Conclusion: The Future of Belgian Federalism-between Reform and Swansong? Regional and Federal Studies, 23 (3), 370.

The World Bank, 2020. The World Bank in Bosnia and Herzegovina [online]. Available from: https://www.worldbank.org/en/country/bosniaandherzegovina [Accessed 1 August 2020].

“Washington Agreement," 1995. Peace Agreements Digital Collection. United States Institute of Peace. Available from: http://www.usip.org/sites/default/files/file/resources/collections/ peace_agreements/washagree_03011994.pdf [Accessed 16 March 2021].

Watts, R.L., 1999. Comparing Federal Systems. London, Montreal and Kingston: McGillQueen's University Press, 7.

World Bank Group, 2020. Stories of Impact: Building Back Better in Bosnia and Herzegovina. Available from: http://documents1.worldbank.org/curated/en/689131494237342559/ pdf/114809-BRI-PUBLIC-soi-bosnia-and-herzegovina.pdf [Accessed 1 August 2020].

World Health Organization Weekly epidemiological update - 12 January 2021. Geneva: WHO, 2021. Available from https://www.who.int/publications/m/item/weekly-epidemiologicalupdate 